\title{
Evaluation of the Infiltration Capacity of Soils in Akpabuyo Local Government Area of Cross River, Nigeria
}

\author{
Eze Bassey Eze, Devalsam Imoke Eni \& Oko Comfort (Corresponding author) \\ Department of Geography and Regional Planning, University of Calabar, P.M.B. 1115, Calabar, Nigeria
}

Tel: 234-703-198-5619 E-mail: devimoke@yahoo.com

Received: February 9, 2010 Accepted: February 23, 2010 doi:10.5539/jgg.v3n1p189

\begin{abstract}
The study evaluates the infiltration capacity of soils in Akpabuyo Local Government Area of Cross River State. The double ring infiltrometer with inner ring of $30 \mathrm{~cm}$ and outer ring of $50 \mathrm{~cm}$ diameter with a height of $30 \mathrm{~cm}$ above the ground was used by the researcher to measure infiltration rates on bare and crusted lands, sparsely vegetated and forested surfaces. Three runs were done at each location. Soil samples were collected from ten sampling points using a soil auger at a depth ranging from $0-15 \mathrm{~cm}$. Samples on soil types were collected because it was believed that soil type greatly influences the rate of infiltration in soil. The results revealed that the mean of sand, silt and clay was 70.3, 15.4 and 14.3 per cent respectively. This shows that the soil in the study area was dominated by sandy soil. The "crust factor" calculated for the area of study was 0.0530 . Also the research revealed that the mean of infiltration rate for forested surface with value of $158.8 \mathrm{~mm} / \mathrm{hr}$ was higher than that of sparsely vegetal and bare surfaces which have values of 66.5 and $8.43 \mathrm{~mm} / \mathrm{hr}$ respectively. Wanton destruction of vegetal cover promotes surface sealing by direct raindrop impact on soil surface and it has inhibited rapid percolation of water on the bare surface of the study area. It is recommended that to improve physical properties and infiltration rate of soils in the study area afforestation should be encourage to cushion the effect of deforestation.
\end{abstract}

Keywords: Infiltration, Soils, Runoff and vegetal cover

\section{Introduction}

Infiltration can be considered as the process by which water from the surface moves into the ground. It can be referred to as the absorption of available water either through rain, ice or any other sources on the soil surface through the soil pore spaces. Several factors affect infiltration rate of a given soil type, these include the nature of the soil layer, the moisture content of the soil, rainfall intensity, temperature, vegetation cover, hydraulic characteristics, permeability and moisture content (Amin, 2005). Water in excess of infiltration capacity of the soil will flow overland as surface run-off once the minor undulations in the surface have been filled. Runoff occurs most frequently on degraded soils depending on topography and rainfall intensity. This phenomenon is common in tropical landscapes of the world, dominated by unwholesome landuse practices. Runoff resulting from low infiltration capacity of soil accelerate erosion process and contributes to the flooding of regional lowlands and streams. The occurrence of surface runoff and other problem associated with excess infiltration above the threshold value of soil is traceable to high intensity rainfall.

Wood and Finger (2007) are of the opinion that variation in the rate of infiltration across the soils in Australia is due to high rainfall, landuse type, the vegetation cover, temperature, and geology. Vegetation such as trees and grasses increase infiltration compared to barren land because the leaves help in shielding the soil from severe rainfall impact. It retards surface flow, thereby giving water more time to infiltrate and promotes the activities of burrowing animals and insects.

In Nigeria, the rainforest which covers two percent of the total area is being depleted at an annual rate of 35 per cent from various man induced activities like deforestation, timber logging, fuelwood extraction, urbanization, oil exploration and all forms of landuse practices (Bisong, 2001). Disturbance created by these human activities, impact on soil structure negatively and reduces its ability to provide the necessary ecological function at full capacity to support life forms. Amusan and Anderson (2005), have noted that as the alteration intensifies, the texture, organic matter content, permeability, water holding capacity and infiltration capacities of soils decline. 
Reconnaissance survey reveals that, fine clay particles form in wash that blocks soil pores and promote the development of surface hard pan. This hinders the process of water movement into the soil within the study area. The trend predisposes the inhabitants of this region, who are predominantly farmers to such ecological risks as surface run-off, erosion, soil nutrient loss and flooding. The incessant flooding of the lowland areas at the slighted storm event is traceable to high surface runoff down the basin, and it has untold consequences on none water tolerant crops. It causes water pollution, landslide and destruction of biodiversity. Soil samples collected at different locations revealed the presence of hard pan, cracks and fissures. Such surface indicators portend imminent risk of low soil buffering capacity, since structured hardness of "A" horizon reduces profile storage of water and make tillage difficult (Ashraf, 2006). This study seeks to determine the infiltration capacity of different soils and some soil physical properties which influences infiltration rates of soils in Akpabuyo Local Government Area of Cross River State, Nigeria.

\subsection{Literature review}

There is a link between water cycle, land management and food security in the environment. Urbanization has forcefully changed the hydrology of the study area, thereby resulting to decrease in the amount of rain water that infiltrates the soil as the excess flow becomes runoff. Agnihotri and Yadav (2002) evaluated the differences in infiltration rates of ustifluvent soil under various landuse practices. Landuses were classified into ravines, farmlands, grasslands and forest. The value of 33.1, 8.2 and $6.0 \mathrm{~mm} / \mathrm{hr}$ were recorded for forested land, farmlands and ravine landuse respectively. They concluded that the infiltration rates for forest land was higher than those of farmland and ravines which implies that the two landuse contribute better to soil protection against surface runoff and erosion.

Antigha and Amalu (1999) undertook a research on physical properties and moisture retention characteristics of coastal plain soils of Obufa Esuk and its environs in Calabar South East Nigeria. It revealed a mean infiltration rates of $33.5 \mathrm{~cm} / \mathrm{hr}$ and $12.3 \mathrm{~cm} / \mathrm{hr}$ for forested and bare lands respectively. A correlation of infiltration rates and hydraulic conductivity recorded values of $0.61,0.71$ and 0.21 when hydraulic conductivity was related to sand, silt and clay contents of the soils. The high values of infiltration rates discovered from this study makes the soil unfit for surface irrigation and for large scale crop production. These findings provide insight on sustainable landuse decision making but remain silent on measures to improve the productive capacity of such soils. Schwab et al, (1995), had recommended the use of soil additives to improve soils infiltration rate and their moisture retention capacities. These includes fine clays that swell and seal soil pores to reduce infiltration rate, plastic films applied to surface soils to decrease rapid rate of infiltration and the introduction of leguminous crops like cowpea, mucuna and alfalfa especially in temperate regions to improve soil textural characteristics.

A range of landuses and water management practices have been proposed to address the negative impacts of unsustainable landuse for the benefit of man at the local and regional scales. These include improved water used efficiency, conjunctive use of surface and ground water and mechanical solutions such as improved drainage (Datta et al, 2004). Dietz et al (2003) opine that the minimization of ecological foot prints of landuse activities remain a difficult task because concerted effort for common actions across regional and national scale are difficult to achieve. The study of infiltration rates come in handy in many hydrological problems such as runoff estimation, soil moisture budgeting and in irrigation planning.

Infiltration studies in the urban milieu shows that vegetation is one of the most paramount parameter affecting surface entry of water into the soil according to Ayoade, (1988). In cities, stones, bricks, concretes and asphalt have replace fields, farms and forests resulting to the bare surfaces been severely crusted. Kigne (2006) opines that urbanization is the most forceful of all changes that affect the hydrology of an area. This consequently brings about a decrease in the volume of rain water that percolates the soil as the excess flow becomes surfaces runoff.

The author clearly has shown that infiltration on bareground takes $8.43 \mathrm{~mm} / \mathrm{hr}$ whereas it is up to $188.8 \mathrm{~mm} / \mathrm{hr}$ under vegetated surface. Forest cover aids in high infiltration which in turn conserve the soil through afforestation practices and can be a good tool for flood control strategy. According to Saiko and Zonn (2000) afforestation practices discourage rain drop compaction by provide a strata of decomposing organic matter which enhances the activities of burrowing insects and animals.

Agnihotri and Yadav (2002) in the city of Agra, India evaluated the variation rates of fluvent soil under landuse practices and forest. In forest land, the value of 33.1 was recoded while farmlands had 8.2. For ravine, the infiltration rate was $6.0 \mathrm{mmh}^{-1}$. The hydraulic conductivity $(\mathrm{Ks})$ range was between $10.9 \mathrm{KS}\left(\mathrm{mmh}^{-1}\right)$ and $9.7 \mathrm{~K}$ $\left(\mathrm{mmh}^{-1}\right)$. It was concluded that the infiltration rate for farmlands and ravines were lower than that of forest and grasslands. This denotes that two landuses contribute better to soil conservation against surface runoff and 
erosion than ravines and farmlands. The area of study is situated within the tropics of Nigeria marked with dry and rainy seasons which is likely to affect infiltration rate of soils due to variations in soil moisture regime. Ayoade (2004) emphasized that both the rainy and dry seasons of the year should be covered by field observation for accurate estimation of average infiltration.

Saiko and Zonn (2003) in a rural district of Ndola in Tanzania carried out a detailed study analysis of infiltration rates of soils under different landuses to ascertain their strength to surface runoff and erosion. He categorized landuses into fallowland and farmland with a range of 6-7 years mean length. The infiltration rate was discovered to be slower in farmland than in cultivated land with values of 36.3 and 72.0 percent respectively. The researchers inferred that soils under fallow are less vulnerable to surface erosion. Soil treatment administration was employed as a strategy for improving infiltration capacity of soils. The authors observed that the cumulative infiltration at an interval of one hour varied widely between 47 and $150 \mathrm{~cm}$ which is dependent on the sampling time and location along the slope. They opined that traditional tillage followed by series of manual cultivation significantly decreases cumulative percolation.

\subsection{Geology, soil and vegetation of the study area}

The area falls within the Precambrian Basement Complex of Oban massif Overlain by cretaceous to tertiary sediments of the Calabar flank (Ekwueme, 2003). The rocks are unconformably overlain by sedimentary sequence of calcareous sandstones with mineral contents of quartz, clay, calcite and fossils occurring as ridge. Clay minerals easily clog soil pores and reduce their infiltration capacity. High concentration of ferromagnesium minerals in soils also affects hydraulic conductivity with the consequence on surface crusting and compaction. The landscape has a gentle slope within undulating topography.

The soils are laterite rich in clay content. Laterites are essentially residue products formed under distinctive climatic conditions in tropical regions. The soils appear reddish in colour, sticky and plastic when wet, it also contain fine particle that easily form in wash capable of lowering the rate of infiltration during storm. Such soils are quick in developing surface pan during wet weather but the presence of organic matter content resulting from thick vegetal cover promotes the rate of biological activity of the soil which helps to improve the soil fertility status.

The vegetation is made up of tall trees with a height of about $36 \mathrm{~m}$. It is luxuriant, dense and generally classed as high forest made up of lower, middle and upper storeys. The lower storey consists of trees between $2 \mathrm{~m}$ and $5 \mathrm{~m}$ in height including shrubs and fens. The middle storey constitutes of dark green dense foliage of about 20 to $30 \mathrm{~m}$ in height. Numerous hard and soft species of wood like mahogany, Iroko, Obeche among others form the upper storey.

\subsection{Method of study}

This study made use of the double ring infiltrometer with inner ring of $30 \mathrm{~cm}$ and outer ring $50 \mathrm{~cm}$ diameter each had a height of $30 \mathrm{~cm}$ above the ground. The double ring infiltrometer was used for the field experiments because of the high rainfall, relative humidity, temperature and evapotransportation which characterized the study area. Although it has some disadvantages such as the disturbance of soil structure, lateral flow of water into drier surrounding and the sampling of small area of land at a time. Infiltration test was carried out at selected sites such as bare crusted, sparsely vegetated and grass-covered/forested surfaces. Three runs were done at each location depending on the rate at which water soaked into the soil.

Mean infiltration rate was computed for bare and crusted, sparsely vegetated with $50 \mathrm{~cm}$ depth of litter cover. The ratio of the steady state infiltration rate of bare surface divided by the steady state infiltration rate of vegetated soils was designated "crust factor".

The infiltrometer was driven into the soil at a depth of $5 \mathrm{~cm}$ with the aid of a sledge hammer and care was taken to ensure that it creates minimum disturbance to the soil. The outer ring acts as a buffer ensuring a vertically downward movement of water. The infiltrometer was flooded at a constant $5 \mathrm{~cm}$ depth throughout the duration of each test run. The process continued until a steady state was reached. Soil samples were collected from ten (10) sampling locations using soil auger at a depth of $0-15 \mathrm{~cm}$. The samples were air dried in an oven, crushed to finer particles and sieved using a $2 \mathrm{~cm}$ sieve and then stored in fresh clean polythene bags in the refrigerator at $2^{0} \mathrm{C}$ between 7-14 days so as to maintain the stability of samples without significant alternation in the biological properties. Sample on soil types were collected because it was believed that soil type greatly influences the rate of infiltration in soil. Porosity was calculated by using the formula below:

$$
\operatorname{Porosity}(\mathrm{n})=\frac{\mathrm{Vt}-\mathrm{Vs}}{\mathrm{Vt}} * 100
$$


Where:

$\mathrm{N}=$ Porosity

$\mathrm{Vs}=$ Volume of dried sample from an oven

$\mathrm{Vt}=$ Total volume of undisturbed sample

Hydraulic conductivity was calculated as follows:

$$
\mathrm{K}=\mathrm{T} / \mathrm{b}
$$

Where:

$\mathrm{K}=$ Hydraulic conductivity

$\mathrm{T}=$ Transmissivity $\left(\mathrm{m}^{2} / \mathrm{s}\right)$

$\mathrm{B}=$ Aquifer thickness $(\mathrm{m})$

\subsection{Results and discussions of findings}

Table 1 show that the soil of the area contains high proportion of sand which is within the ranges of 60.1-81.4 per cent. This is followed by silt, which ranged from 11.3-19.5 per cent and clay 3.2-22.1 per cent. The mean values for sand silt and clay were 70.3, 15.4 and 14.3 per cent respectively. This indicates that the soils in the study area are mainly sandy. The research further reveals that the soils have loamy sand to sandy surface. Permeability is a major parameter that determines the flow of water through the soil strata. It was observed that clay soil was porous but not permeable. The amount of pore spaces in an individual soil layer is a function of the sorting grain shape, packing and degree of compaction (Babalola, 1988).

All the samples collected reveals that clay content with the lowest mean of $14.3 \%$ is mostly Kaolinite with low water and nutrient holding capacities, and are susceptible to erosion once the vegetal cover is destroyed. The high concentration of sand fraction in Akpabuyo suggest that the soils are likely to disintegrate on quick wetting because of the low clay and organic matter content especially in the surface horizons.

Table 2 shows that Ikot Mandu had the highest porosity of 28 per cent with a hydraulic conductivity of $15 \mathrm{~mm} / \mathrm{hr}$ and it is dominated by vegetated surface. The result posits that infiltration rates for vegetated surface were higher than those of the bare crusted and sparsely vegetated surfaces. It implies that the vegetated landuse contributes better to soil protection against surface runoff and erosion than bare crusted and sparsely vegetated surface in the study area. The research also reveals that porosity is a measure of the water bearing capacity of a soil and it plays a role in the determining the capability of the soil to transmit water.

The results in Tables 3 and 4 reveal that the study of infiltration rate is very important in an environment that is sensitive to changes in the protective cover of vegetation. They also show that infiltration rates is higher in forested and grass covered soils, ranging from $75.6 \mathrm{~mm} / \mathrm{hr}-220 \mathrm{~mm} / \mathrm{hr}$ with mean value of $158.8 \mathrm{~mm} / \mathrm{hr}$. The removal of the vegetation cover reduces infiltration rate as shown in the Table 4 where the bare and crusted surface had a mean value of $8.43 \mathrm{~mm} / \mathrm{hr}$.

The research shows that destruction of the vegetal cover promotes surface scaling by direct raindrop impact on soil surface, which inhibits rapid percolation of water. The infiltration rates for sparsely vegetated surfaces ranged from $26.3-40.5 \mathrm{~mm} / \mathrm{hr}$ with a mean value of $25.9 \mathrm{~mm} / \mathrm{hr}$. It is clear from these figures that exposure of the soils to direct raindrop destroys the soils structure.

The study revealed that soil structure is the most vulnerable physical property of the soil when vegetation cover is destroyed. Structurally unstable soils are readily slaked and tend to form a semi-permeable surface crust which leads to concentration of runoff on slopes. Calculating the "crust factor" which is the ratio of the infiltration rate of the bare and crusted surface to that of vegetated surface it gave a value of 0.0530 as shown below.

$$
\text { Crust factor }=\frac{\text { Mean of bare } / \text { crusted surface }}{\text { Mean of vegetated surface }}=\frac{8.43}{158.8}=0.0530
$$

Figure 1 shows that vegetated surface had the highest infiltration rate within the study area. This was followed by sparsely vegetated surface bare and crusted surface had the lowest infiltration rates. Vegetated surface is believed to encourage high infiltration and thus reduces overland flow which in turn conserves the soil.

Figure 2 shows sampling points from which soil samples were collected and measurements made during the course of this research. 


\section{Testing of hypothesis}

A one way analysis of variance was used to test the hypothesis which states that there is no significant difference in infiltration rate between bare and crusted surface in the study area. The result was present in Table 5,6 and 7.

Table 5 shows the descriptive statistics of the variables under study. The table reveals that the mean infiltration for bare and crusted surfaces was 8.43 (unit). The mean infiltration rate for sparsely vegetated surface is 31.60 (unit) while that for vegetated surface is 158.80 (unit). This shows that the rate of infiltration in vegetated surface is higher than those $\mathrm{n}$ other surface.

Akintola (1974) worked on the variability of infiltration parameters as introduced by different landuse surfaces in Ibadan. Parameters as introduced by different landuse surfaces in Ibadan. He grouped landuse surfaces into bare ground, highly disturbed grass, undisturbed grass, farmland and forest. The mean infiltration capacity for highly disturbed grass and undisturbed grass recorded 270 and $490 \mathrm{~mm} / \mathrm{hr}$. While forest area had the highest reading of $1000 \mathrm{~mm} / \mathrm{hr}$. The implication is that at a given rainstorm event runoff would be greatly reduced in vegetated areas than in bare and crusted surfaces. Heavy runoff could lead to gully erosion and depletion of soil fertility. Most areas in Akpabuyo local government area are already threatened by gullies with the current rates of deforestation and development which may get out of control if not probably handled.

Table 6 and 7 is the result of the analysis of variance in the infiltration rates among the three different land covers in the study area. The result shows a significant variation as $\mathrm{F}=121.125$ having a significant value of less than 0.001 . The Scheffe's post hoc was conducted to show the effectiveness or ineffectiveness of test each group in the phenomenon being investigated. The result shows that infiltration in bare and crusted surface is not significantly different from those on sparsely vegetated surface. Hence, these two land covers are ineffective in explaining the variation in the phenomenon. However, the infiltration rate in vegetated surface is significantly different from those on bare and crusted surface and sparsely vegetated surface. The effectiveness of the variation therefore lies with the vegetated surface.

\section{Conclusion}

Studies on infiltration rates of soils are required in solving many hydrological problems such as runoff estimation, soil moisture budgeting irrigation planning, landuse planning and management. This research shows that vegetation cover is one of the most important factors that accelerates infiltration rate and thus reduces overland flow which and ultimately in turns conserves the soil. The mean for vegetal cover was as high as $158.8 \mathrm{~mm} / \mathrm{hr}$. The sand, silt and clay contents of the soils had mean values of 70.3, 15.4 and 14.3 per cent which shows that the area is dominated by sandy soil. The area is unsuitable for surface irrigation due to its high infiltration capacity.

It is recommended that human activities in the form of deforestation, bush burning and grazing by livestock should be discouraged, while in this area; planting of trees on bare lands should be encouraged to reduce erosion.

\section{References}

Abua, M. A. \& Edet, E. O. (2007). Morphological and physico-chemical characteristics of coastal plain soils of southern Cross River State-Nigeria. The Nigerian Journal of Geography and Environment, 5(1), 109-114.

Agnihotri, R. \& Yadav, R. (2002). Evaluation of infiltration capacity of ustifluvent soils susceptible to gully. Journal of hydrological science, 37, 399-606.

Akpan, I. (2006). Soil fertility Text of Itigidi Flood plains in Cross River State-Nigeria. Soil Science, (7), 3.

Amin, M. (2005). Spatial Variability of infiltration in Watershed. Journal of Hydrology, 45, 101-122.

Amusan, B., Ball, E. \& Anderson, G. (2005). Changes in characteristics of a degraded soil under fallow in south western Nigeria. Journal of Agricultural Engineering, 4, 12-17.

Antigha, N. \& Amalu, U. (1999). Physical properties and moisture retention characteristics of some coastal plain soils in Calabar south-east Nigeria. Global Journal of Pure and Applied Science, (6) 2-10.

Ashraf, M. and Saced, M. (2006). Effect of Improved cultural practices on crop yield and soil salinity under relatively saline ground water applications. Journal of Irrigation and Drainage, 20, 111-124. doi:10.1007/s10795-006-1719-4, http://dx.doi.org/10.1007/s10795-006-1719-4

Ayoade, J. O. (2004). Introduction to Climatology for the tropic. Ibadan, Spectrum Book.

Babalola, O. (1988). Soil properties affecting infiltration, runoff and erodobility in Enabor, E. et al (eds) Ecological disasters in Nigeria: Soil Erosion, Federal Ministry of Science and Technology, Lagos 10, 131-136. 
Bisong, F. E. (2001). Natural resource use and conservation for sustainable rural development, BAAJ Publisher (Chapter 2) 69-80.

Datta, K. K. \& Joshi, P. K. (2004). Impact of surface drainage on the improvement of crop production and farm income in North West India. Irrigation and Drainage Systems, 18:43-56. doi:10.1023/B:IRRI.0000019475.42469.33, http://dx.doi.org/10.1023/B:IRRI.0000019475.42469.33

Diamond, J. (2004). Buck Density Determination of Chlonroche Country Soils. Irish Geography, (36), 2.

Dietz, T., Ostron, E. \& Sten, P. C. (2003). The struggle to govern the common. science, 302, 1907-1912.

Don-Scott, H. (2000). Soil Physics: Agricultural Environmental Application; Lowa, Lowa State University Press.

Dumin, F. (2002). Integrating Agroforestry and perennial partners to mitigate water logging to secondary salinity. Agriculture water management Journal, 53, 259-270.

Fajimori, S. \& Matsuoka, Y. (2007). Development of Estimating Method of Global Carbon, Nitrogen and Phosphorus flow caused by Human Activity. Ecological Economics, 62, 399-418. doi:10.1016/j.ecolecon.2007.02.016, http://dx.doi.org/10.1016/j.ecolecon.2007.02.016

Gish, P. C. \& Hains, J. H. (2004). Regional scale effects of flow regulations on lowland riverine fish communities in New South Water, Australia. Research and Management, 17, 369-391.

Kham, S. \& Rana, T. (2007). Conjunctive management options examples from Economic Assessment of Lucyllan Kou Irrigation systems, China. Irrigation and Drainage, 56: 523-539.

Kigne, J. W. (2006). Salinization in irrigated Agriculture in Pakistan: Mistaken Predictions. Water Policy, 8 , 325-338.

Lucyllan Kou Irrigation systems, China. Irrigation and Drainage, 56, 523-539.

Melvis, E. G. (2001). Landuse and Water Resources in temperate and tropical climates. Cambridge, Cambridge

Raghunath, H. (2008). Hydrology: Principles Analysis and Design, New Delhi, New Age International Publishers (Chapter 8) 76-84.

Rhohon, F. E., Romkoms, J. \& Bogham, T. M. (2003). Ferenhydrite influence on infiltration, runoff and soils loss. Soil science society of American Journal, 67, 1200-1226.

Rose, C. (2008). Water transport in soil with a daily temperature wave: Theory and Experiment. Australia Journal of soil Research, (6), 3-23.

Saiko, T. A. \& Zonn, I. S. (2003). Landuse and Management Impacts on structure and infiltration characteristics of chio-soil. Science, 169, 167-177.

Schwab, A., Fangmeir, D., Elliot, I \& Frerert, K. (1995). Soils and Water Conservation Engineering. New York, John Wiley \& Sons Inc. (Chapter 12) 15-35.

Udosen, C. (2008): Gully erosion in Ikpa River Basin; a threshold phenomenon. Lagos: Time Communication (Chapter 1) 10-30.

Wood, M. \& Finger, L. (2006). Influenced of irrigation method on water use and production period partners in Northern Victoria-Australian Journal of Experimental Agriculture, 46, 1604-1614. doi:10.1071/EA05197, http://dx.doi.org/10.1071/EA05197 
Table 1. Physical characteristics of soil obtained from Akpabuyo Local Government Area

\begin{tabular}{|c|c|c|c|c|}
\hline S/NO & SAMPLE POINTS & SAND\% & SILT \% & CLAY \% \\
\hline 1. & Ikpa & 72.2 & 18.6 & 9.2 \\
\hline 2. & Idundu & 67.3 & 12.5 & 20.2 \\
\hline 3 & Akansoko & 81.0 & 14.4 & 4.6 \\
\hline 4 & Eto Mkpe Archibong & 73.0 & 11.3 & 15.7 \\
\hline 5 & Ikot Effanga & 81.4 & 15.4 & 3.2 \\
\hline 6 & Ikot Ndarake & 70.5 & 13.4 & 16.1 \\
\hline 7 & Esuk Mbat & 61.4 & 17.5 & 21.1 \\
\hline 8 & Ikot Ekpo & 63.3 & 14.6 & 22.1 \\
\hline 9 & Ikot Nakanda & 73.0 & 16.3 & 10.7 \\
\hline 10 & Ikot Mandu & 60.1 & 19.5 & 20.4 \\
\hline & Mean & $\mathbf{7 0 . 3}$ & $\mathbf{1 5 . 4}$ & $\mathbf{1 4 . 3}$ \\
\hline
\end{tabular}

Table 2. Soil Properties in the Study Area

\begin{tabular}{|c|c|c|c|}
\hline S/NO & SAMPLE POINTS & POROSITY (PERCENT) & $\begin{array}{c}\text { HYDRAULIC CONDUCTIVITY } \\
\mathbf{m m} / \mathbf{h r} \text { (m/d) }\end{array}$ \\
\hline 1. & Ikpa & 25 & 11 \\
\hline 2. & Idundu & 2 & 10 \\
\hline 3 & Akansoko & 10 & 6 \\
\hline 4 & Eto Mkpe Archibong & 18 & 9 \\
\hline 5 & Ikot Effanga & 15 & 11 \\
\hline 6 & Ikot Ndarake & 16 & 2 \\
\hline 7 & Esuk Mbat & 5 & 14 \\
\hline 8 & Ikot Ekpo & 20 & 8 \\
\hline 9 & Ikot Nakanda & 12 & 15 \\
\hline 10 & Ikot Mandu & 28 & \\
\hline
\end{tabular}


Table 3. Impact of vegetative cover removal on infiltration rates in $\mathrm{mm} / \mathrm{hr}$

\begin{tabular}{|c|c|c|c|c|}
\hline S/No & Location & Bare and crusted surface & $\begin{array}{l}\text { Sparsely vegetated } \\
(3 \mathrm{~cm} \text { litter cover) }\end{array}$ & Vegetated surface \\
\hline \multirow{3}{*}{1.} & \multirow{3}{*}{ Ikpa } & 6.5 & 30.6 & 220.0 \\
\hline & & 6.0 & 28.5 & 180.0 \\
\hline & & 5.8 & 26.3 & 160.0 \\
\hline \multirow{3}{*}{2.} & \multirow{3}{*}{ Idundu } & 9.6 & 34.5 & 98.9 \\
\hline & & 8.7 & 31.6 & 86.8 \\
\hline & & 7.5 & 29.5 & 75.6 \\
\hline \multirow{3}{*}{3.} & \multirow{3}{*}{ Akansoko } & 11.9 & 28.7 & 108.5 \\
\hline & & 9.6 & 26.5 & 96.7 \\
\hline & & 8.7 & 24.3 & 92.6 \\
\hline \multirow{3}{*}{4.} & \multirow{3}{*}{ Eto Mkpe Archibong } & 12.7 & 39.5 & 190.5 \\
\hline & & 8.8 & 36.6 & 185.6 \\
\hline & & 6.5 & 33.2 & 170.3 \\
\hline \multirow{3}{*}{5.} & \multirow{3}{*}{ Ikot Effanga } & 8.5 & 40.6 & 200.5 \\
\hline & & 7.6 & 38.5 & 187.5 \\
\hline & & 6.0 & 37.4 & 176.5 \\
\hline \multirow{3}{*}{6.} & \multirow{3}{*}{ Ikot Ndarake } & 10.5 & 35.5 & 185.5 \\
\hline & & 8.6 & 33.4 & 170.5 \\
\hline & & 6.0 & 30.5 & 162.5 \\
\hline \multirow{3}{*}{7.} & \multirow{3}{*}{ Esuk Mbat } & 7.9 & 32.5 & 240.5 \\
\hline & & 6.3 & 31.3 & 215.5 \\
\hline & & 5.9 & 29.6 & 180.0 \\
\hline \multirow{3}{*}{8.} & \multirow{3}{*}{ Ikot Ekpo } & 9.3 & 37.6 & 170.5 \\
\hline & & 8.6 & 32.1 & 140.0 \\
\hline & & 7.4 & 30.0 & 135.5 \\
\hline \multirow{3}{*}{9} & \multirow{3}{*}{ Ikot Nakanda } & 8.6 & 29.5 & 165.5 \\
\hline & & 7.5 & 27.3 & 135.5 \\
\hline & & 6.6 & 26.1 & 120.5 \\
\hline \multirow{3}{*}{10} & \multirow{3}{*}{ Ikot Mandu } & 13.4 & 31.5 & 198.5 \\
\hline & & 11.5 & 28.6 & 165.0 \\
\hline & & 10.2 & 26.5 & 150.5 \\
\hline
\end{tabular}


Table 4. Mean for the impact of vegetal cover removal on infiltration rates in $\mathrm{mm} / \mathrm{hr}$

\begin{tabular}{|c|c|c|c|c|}
\hline S/No & Location & Bare and crusted surface & $\begin{array}{c}\text { Sparsely vegetated } \\
\text { (3cm litter cover) }\end{array}$ & Vegetated surface \\
\hline 1. & Ikpa & 6.1 & 28.5 & 186 \\
\hline 2. & Idundu & 8.6 & 31.9 & 87.1 \\
\hline 3. & Akansoko & 10.1 & 26.5 & 99.3 \\
\hline 4. & Eto Mkpe Archibong & 9.3 & 36.4 & 182.1 \\
\hline 5. & Ikot Effanga & 7.4 & 38.8 & 188.2 \\
\hline 6. & Ikot Ndarake & 8.4 & 33.1 & 172.8 \\
\hline 7. & Esuk Mbat & 6.7 & 31.1 & 212 \\
\hline 8. & Ikot Ekpo & 8.4 & 33.2 & 148.7 \\
\hline 9 & Ikot Nakanda & 7.6 & 27.6 & 140.5 \\
\hline 10. & Ikot Mandu & 11.7 & 28.9 & $\mathbf{1 8 8 . 8}$ \\
\hline
\end{tabular}

Table 5. The descriptive statistics of the variables under study

\begin{tabular}{|c|c|c|c|c|c|c|}
\hline & \multirow[t]{2}{*}{$\mathbf{N}$} & \multirow[t]{2}{*}{ Mean } & \multirow[t]{2}{*}{ Std Deviation } & \multirow[t]{2}{*}{ Std Error } & \multicolumn{2}{|c|}{$\begin{array}{l}95 \% \text { confidence interval } \\
\text { for mean }\end{array}$} \\
\hline & & & & & Lower Bound & Upper Bound \\
\hline Bare and crusted surface & 10 & 8.4300 & 1.64793 & .52112 & 7.2511 & 9.6089 \\
\hline Sparsely vegetated surface & 10 & 31.6000 & 3.92909 & 1.24249 & 28.7893 & 34.4107 \\
\hline Vegetated surface & 10 & $1.5880 \mathrm{E} 2$ & 40.06608 & 12.67001 & 130.1384 & 187.4616 \\
\hline Total & 30 & 66.2767 & 70.88207 & 12.94124 & 39.8089 & 92.7445 \\
\hline
\end{tabular}

Table 6. ANOVA Infiltration Rate

\begin{tabular}{|c|c|c|c|c|c|}
\hline & Sum of squares & df & Mean square & F & sig \\
\hline Between Groups & 131092.753 & 2 & 65546.376 & & \\
Within Groups & 14611.001 & 27 & 541.148 & 121.125 & .000 \\
Total & $\mathbf{1 4 5 7 0 3 . 7 5 4}$ & 29 & & \\
\hline
\end{tabular}

Table 7. Multiple comparison post Hoc Tests

\begin{tabular}{|l|l|l|l|l|}
\hline (I) Vegetal Cover & (J) Vegetal Cover & $\begin{array}{c}\text { Mean difference } \\
\text { (I-J) }\end{array}$ & Standard error & sig \\
\hline Bare and crusted surface & Sparsely vegetated surface & -23.17000 & 10.40335 & .103 \\
& Vegetated surface & $-150.36000^{*}$ & 10.40335 & .000 \\
\hline Sparsely vegetated surface & Bare and crusted surface & 23.17000 & 10.40335 & .103 \\
& Vegetated surface & $-127.20000^{*}$ & 10.40335 & .000 \\
\hline Vegetated surface & Bare and crusted surface & 150.37000 & 10.40335 & .000 \\
& Sparsely vegetated surface & $127.20000^{*}$ & 10.40335 & .000 \\
\hline
\end{tabular}

*The mean difference is significant at the 0.05 level 


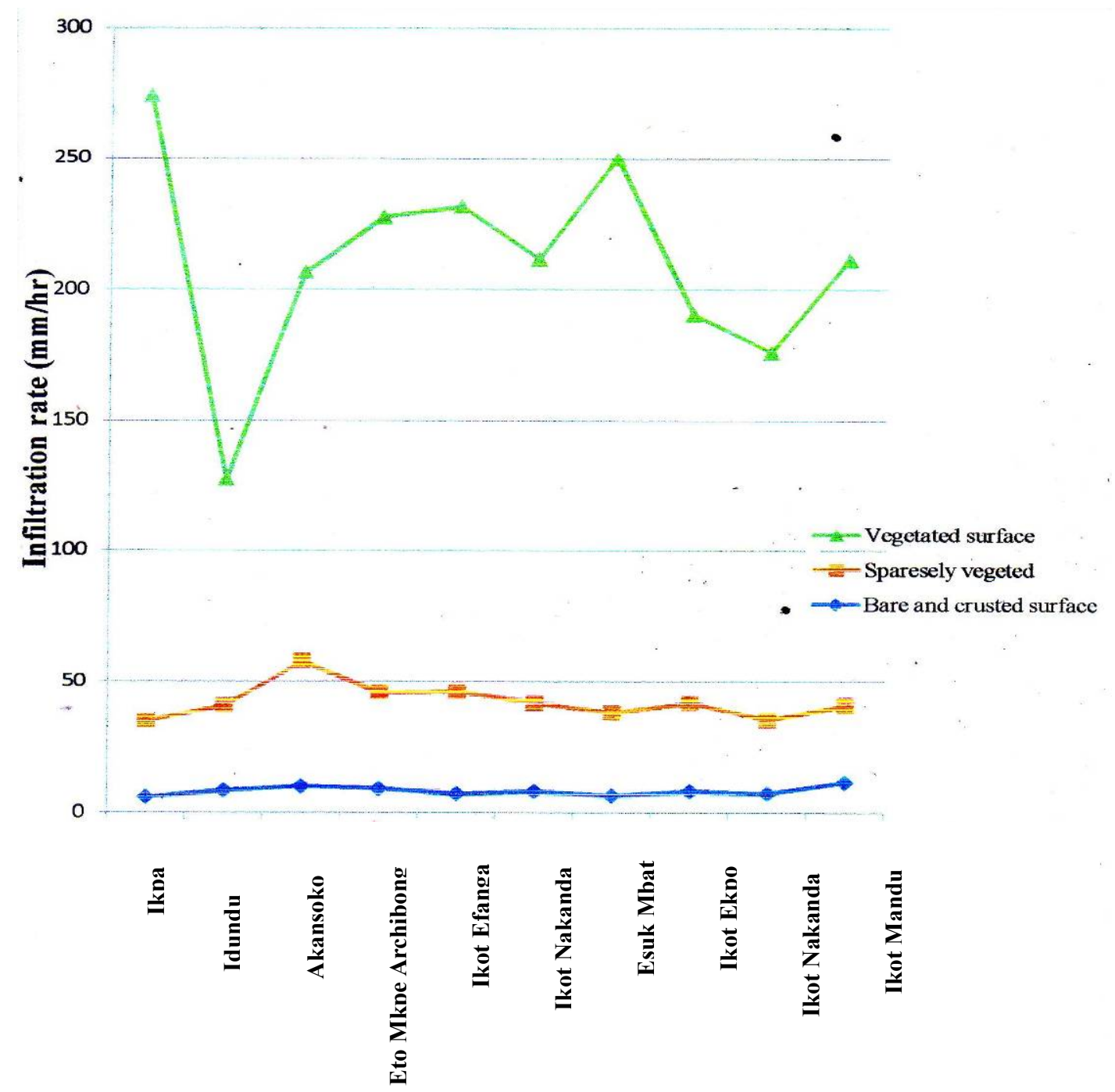

Figure 1. Infiltration rate as affected by the various soil covers in Akpabuyo L.G.A. 


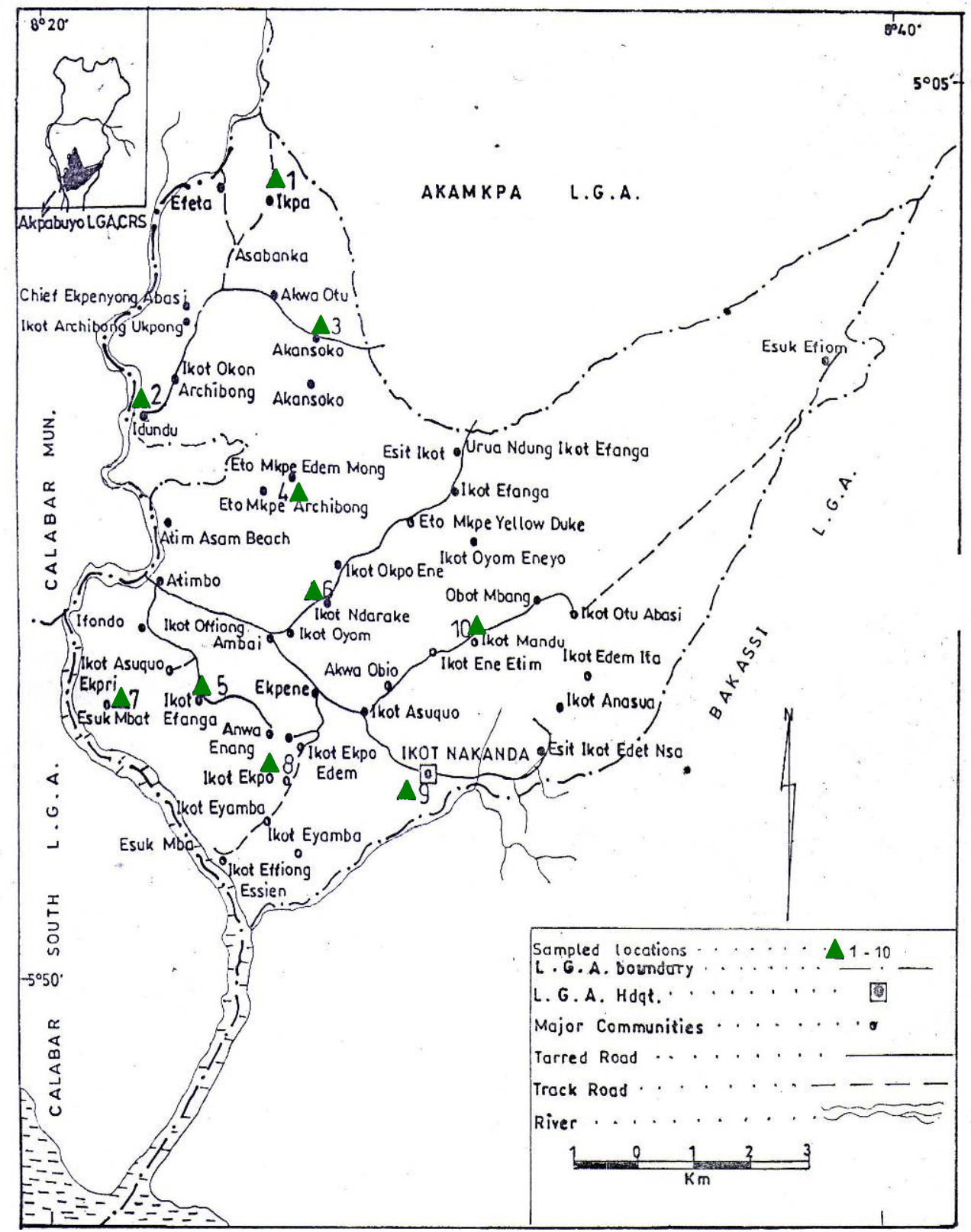

Figure 2. Map Akpabuyo Local Government Area Showing the sampled locations 